臨床 特発性アルドステロン症の 1 家系

\begin{tabular}{lrrrrr}
\multicolumn{8}{c}{ 東北大学医学暗第二队科 } & \\
色川 & 伸夫 & 阿部 & 圭志 & 保嶋 & 実 \\
桜井 & 豊 & 伊藤 & 徹 & 千葉 & 知 \\
齐藤敬太郎 & 大塚 & 庸一 & 吉永 & 馨
\end{tabular}

\title{
A CASE OF FAMILIAL IDIOPATHIC HYPERALDOSTERONISM
}

Nobuo Irokawa, MD, Keishi A be, MD, Minoru Yasujima, MD, Yutaka Sakurai, MD, Toru I to, MD, Satoru Chiba, MD, Keitaro SATto, MD, Yoichi Otsuka, MD, and Kaoru Yoshinaga, MD

The Second Department of Internal Medicine, Tohoku University School of Medicine

(Director: Prof Kaoru Yoshinaga, MD)

\begin{abstract}
概要 症例は17才の女で，3年前に高血圧を指摘され，その後，手足にしびれ感や脱力発作を繰返す ようになり，精查のために入院した。入院時血王は190/120mnHgでCushing病様症状を認めず，外性器 に異常なく，二次性改の発現も正常で，月経は順調(初潮12才）であつた，cortisolは正常，renin分泌 は抑制され，血桨aldosterone濃度は高值を示し，又，低 $\mathrm{K}$ 血奨が認められた. dexamethasone投与にも 血压の降下は認められずglucocorticoid responsive aldosteronism, あるいは既知の醭素欠損症は否定さ れた，右副腎腺腫を疑い右副腎を全摘出したが，腺腫は認められなかつた，術後，血圧は正常化せず， 血浆aidosterone濃度も高值であつた．摘出副腎のaldosterone含壆が高值であつたことより，反対側副 腎の腺腫の存在は否定され，又，組織学的にも副腎皮質の過形成を認めた。これらの結果より，本症 は特発性aldosterone症と診断された，本例の家族歴をみると，母方芥した，いとこ，同胞11人中， 本例を含めて副腎摘出を行ない，組織学的にも特発性aldosterone症之診断されたもの2 例, renin分泌 の抑制，高aldosterone血症，低K血症等を認め特発性aldosterone症の疑いが濃厚であるるの 2 例，計 4 例に本症を認め，本症が家族的に発生していると考えられた。
\end{abstract}

\section{緒 言}

原発性aldosterone症は1955年にConn ${ }^{1)} に よ り$ 初 めて報告された疾患で，その後，数多くの報告が なされている. しかし，臨床症状および検査成績 が同一でありながら，副腎皮質以腺腫を認めず， 両側副腎皮質の過形成によるいわゆる特発性aldosterone症が報告されるようになり，その発生原 因あるいは副腎腺腫による原発性aldosterone症と の鑑別診断が問題となつて来ている．著者らは血 浆renin活性の抑制，高aldosterone血症を副腎皮質

[昭和52年 6 月 10 日 第92回東北地方会推薦] の過形成を伴つた，いわゆる特発性aldosterone症 の 1 例を経験した，本症が家族的に発生している と考えられる成績が家族の検索より得られたので 報告する。

\section{症例}

患者：17才，看護婦.

主訴：高血圧, 脱力発作。

家族歴：高血圧すり，血族結婚はない。

既往歴：特記すべきことなし。

現病歴：昭和49年春, 頭痛があり, 学校の保 健室で血圧の測定をらけ, 初めて高血圧を指摘さ れた $(180 / 90 \mathrm{~mm} \mathrm{Hg})$. その後降俚剂を服用してい 
たが，血圧はコントロール出来なかつた。昭和50 年11月に手足にしびれや脱力発作を綝返すように なつた，夜間尿は $2 〜 3$ 回であつた．昭和51年 3 月に鉒石市民病院を受診し，精查のために東北大 学第二内科に入院した.

入院時現症：身長 $152 \mathrm{~cm}$, 体重 $54 \mathrm{~kg}$, 骨格中 等度, 顔貌正常, 色素沈着はなく, 中心性肥満, 多毛, 痤㾑, 皮唐線条などのCushing様症状を認

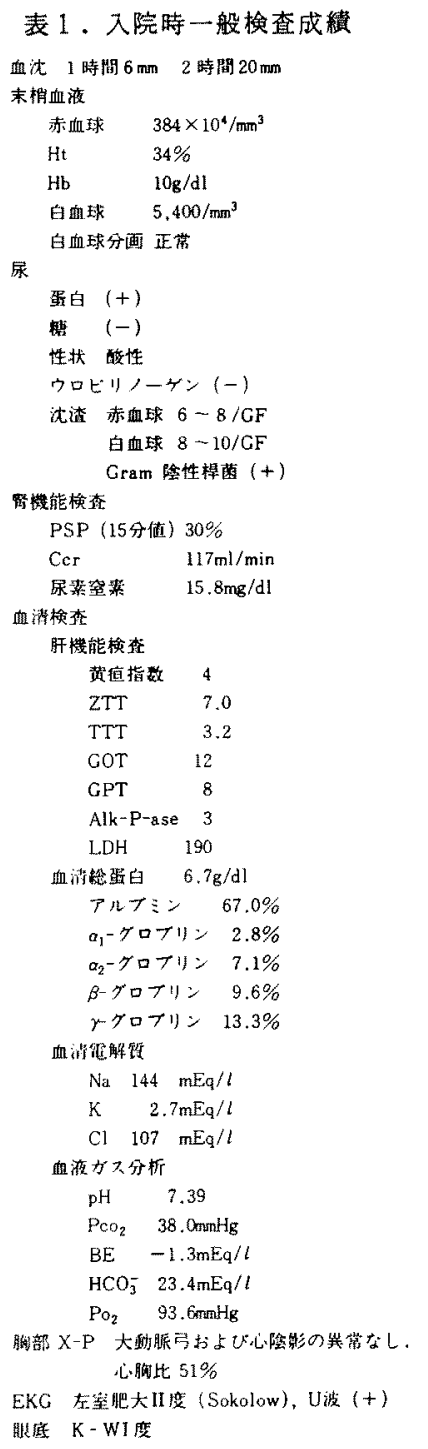

めず。外性器に異常なく，二次性致の発現む正 常.月経は順調 (初潮12才). 血圧は190/120mm と高く, 上下肢㧊よび左右差なし，脈拍は整, 胸 部聴打診では心濁音界は正常で, 心音は清, 肝, 脾，腎は触知せず。背部，腹部に血管䧱音を聴取 せず。浮腫なし. Chvostek徵候やTrousseau徵候な く，その他，神経学的に異常を認めなかつた。

一般検査成績（表 1)：血沈は正常, 軽度の 貧血あり．尿蛋白は陽性で，尿沈查所見で赤血球

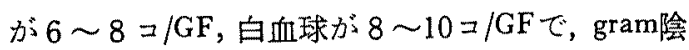
性桿菌を認め, 蛋白尿は尿路感染によるものと考 えられた。腎機能は正常, 肝機能，血清蛋白に異 常を認めず．血清電解質では血清 $\mathrm{K} か ゙ 2.7 \mathrm{mEq} / l$ と 低值. 血液ガス分析では代謝性alkalosisは認め ず，心電図では左室肥大 II 度 (Sokolowの分類 ${ }^{2}$ ) で，U波を認めた。心胸比は51\%。眼底はK-WI 度. 静脈性腎孟造影心異常を認めなかつた。

内分泌検査 (表 2)：尿中17-OHCSは6.0mg/ 日，尿中17-KSは13mg/日と正常. dexamethasone 抑制試験では cortisolが $6.2 \mu \mathrm{g} / \mathrm{dl}$ か らdexamethasone $1 \mathrm{mg}$ 投与で, $1.7 \mu \mathrm{g} / \mathrm{dl}, 8 \mathrm{mg} て ゙ 0.5 \mu \mathrm{g} / \mathrm{dl}$ と抑制

\section{表 2 . 内分泌榆查成樍}

これらの結果よりCushing 疑侯群は否定された。

$\begin{array}{lr}\text { 1) 汖中 17-OHCS } & 6.0 \mathrm{mg} / \text { 日 } \\ \text { 2) 尿中 17-KS } & 13.0 \mathrm{mg} / \text { 日 } \\ \text { 3) dexamethason 抑制試験 } & \text { cortisol } \\ \text { 前 } & 6.2 \mu \mathrm{g} / \mathrm{dl} \\ \text { dexarnethasone 1mg 投与後 } & 1.7 \mu \mathrm{g} / \mathrm{dl} \\ \text { dexamethasone 8mg 投与後 } & 0.5 \mu \mathrm{g} / \mathrm{dl}\end{array}$

表 3．血獎renin活性と血獎aldosterone濃度 血漿 renin 活性:は抑制され，血䈨 aldosterone 濃度は 高䛧であった。

血獎 renin 活性:

1) 安静時: trace

2) lasix (60mg) 绝荷：立位120分保荷後 trace

3 ）三者真荷 (hydrochlorothiazide $75 \mathrm{mg}$ ，無盐食, spironolactone $400 \mathrm{mg}$ ):

安静 $9 \mathrm{ng} / \mathrm{ml}$

立体 120 分 $13.6 \mathrm{ng} / \mathrm{ml}$

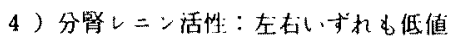

血獎 aldosterone 濃度: $36.4 \mathrm{ng} / \mathrm{dl}$ 
され, Cushing症候群は否定された。

Renin-angiotensin-aldosterone系の検查(表3, 困 1)：血浆renin活性は安静時扣よびfurosemide $60 \mathrm{mg}$ 静注後 2 時間立位負荷後もきわめて低値を示 した. 無塩食とspironolactone 400mg, hydrochlorothiazide $75 \mathrm{mg}$ を 3 日間投与したのち，2 時間立位 を加えるrenin分泌刺激試験 (三者負荷)を行なつ た. 図 1 に原発性aldosterone症の本刺激法による 抑制の籁囲を示した．本症の三者負荷後の安静時 renin活性 が $25 \mathrm{ng} / \mathrm{ml}$ 以下, 立位 120 分後 のrenin活 性が50ng/ml以下をその範囲とした ${ }^{3)}$. 本例の負 荷後安静時のrenin活性は $9 \mathrm{ng} / \mathrm{ml}$, 立位 120 分後が $13.6 \mathrm{ng} / \mathrm{ml}$ とrenin活性は抑制されていた。一方,

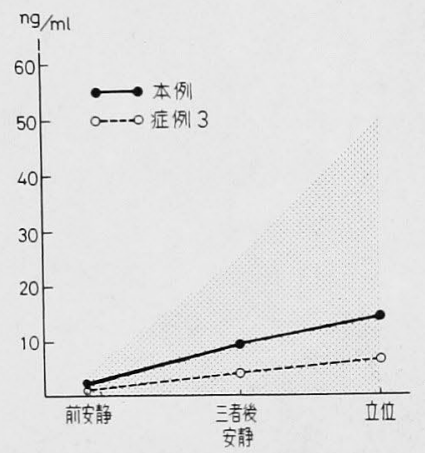

図 1.三者負荷（無塩食, spironolactone $400 \mathrm{mg}$, hydrochlorothiazide $75 \mathrm{mg}$ ) 後の血獎renin活性. 強 力なrenin分泌刺激に対しても，renin分泌は著明に 抑制されていた。 shadow部分は原発性アルドステロ ン症の反応域を示す。

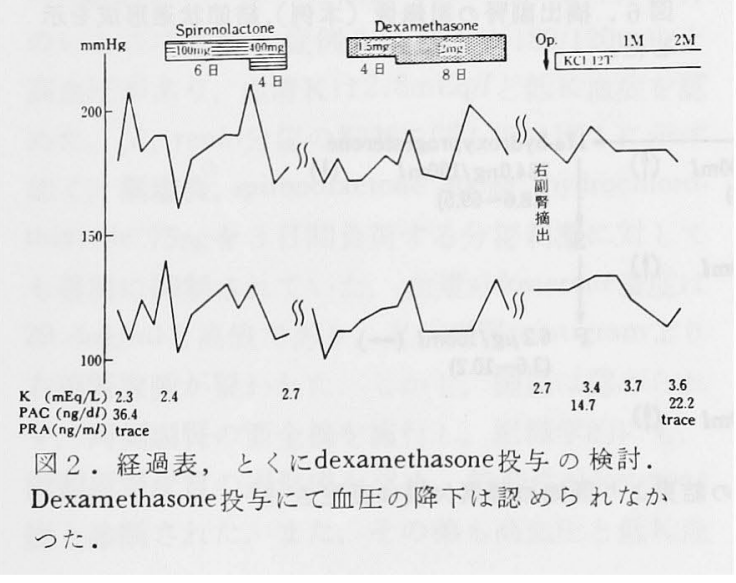

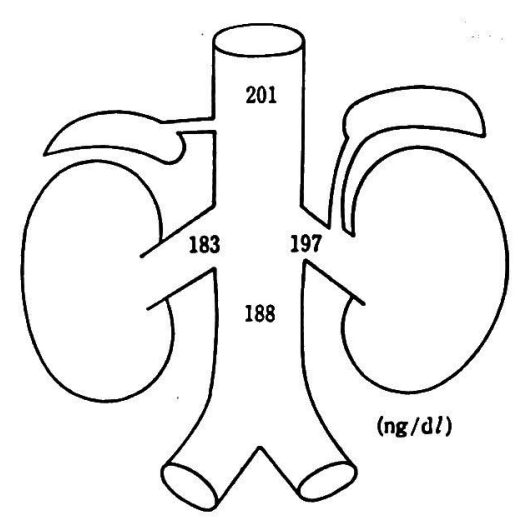

図 3. 腹部大静脈血の血獎aldosterone濃度。静脈血 aldosterone濃度に左右差は認められなかった。

血浆aldosterone濃度は $36.4 \mathrm{ng} / \mathrm{dl}$ と高値を示した。

Dexamethason投与の検討（図 2)：図は術 前の経過を示したものである. dexamethasone $1.5 \mathrm{mg}$ を 4 日間， $2 \mathrm{mg} 8$ 日間の投与を行なつた. 投与前の血圧の平均は収縮期 $177 \mathrm{~mm} \mathrm{Hg}$ ，拡張期 110 $\mathrm{mm} \mathrm{Hg}$ ，平均血圧 $132 \mathrm{~mm} \mathrm{Hg}$ であつたのに対して，投 与後では収縮期 $185 \mathrm{~mm} \mathrm{Hg}$, 拡張期 $124 \mathrm{~mm} \mathrm{Hg}$, 平均血 王 $144 \mathrm{~mm} \mathrm{Hg}$ と血圧の降下は認められず, glucocorticoid responsive aldosteronism ${ }^{4}$ は否定された.

副腎皮質の局在性の検討： 選択的に左右別に 副腎静脈からの採血が出来ず，副腎静脈と思われ る部位で採血を行ない，血䘵aldosterone濃度を測 定し，その結果を図 3 に示した，右副腎静脈と思 われる部位では $201 \mathrm{ng} / \mathrm{dl}$ ，左副腎静脈と思われる 部位では197ng/dl と左右差は得られなかつた。

副腎scintigraphyはdexamethasone $2 \mathrm{mg}$ 投与のも とで行なつた。副腎scintigramを図 4 に示す，右 側に取り込みが多く認められ，右副腎腺腫が疑わ れた。

以上の臨床症状拈よび検査成績より原発性 aldosterone症と診断し，副腎scintigramより右副 腎の腺腫が疑われ手術を施行した。腺腫は確認さ れなかつたが，右副腎を全摘出した，術後，血圧 は正常化せず，血浆renin活性は抑制されており， 血浆aldosterone濃度は術後 2 カ月目で $22.5 \mathrm{ng} / \mathrm{ml}$ と変らず高值であつた。 


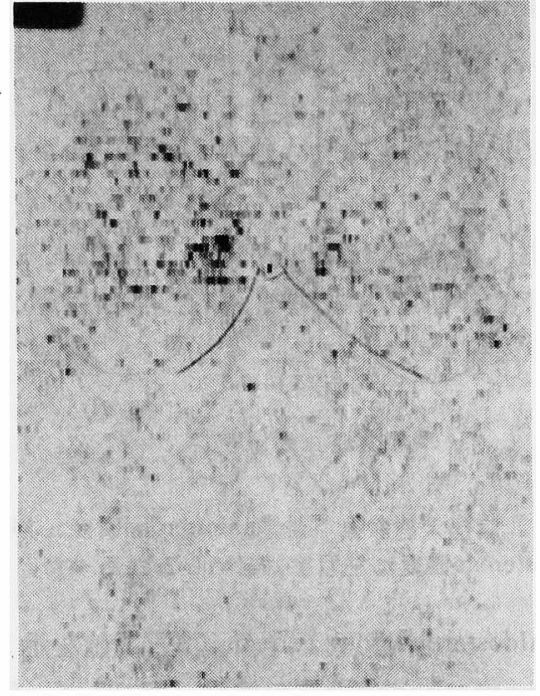

図 4. 副腎scintigram (本例). 右副腎に取り迂みが 多く認められ，右副腎腺腫が籎われた。

摘出副腎の組織aldosterone含量： 反対側副 腎に腺腫が存在するか, 否かを検討するために摘 出副腎の組織中aldosterone含量を測定した. 正常 副腎のaldosterone含量は20 120ng/g tissue, 原発 性aldosterone症の腺腫の組織含量は1000〜7200 ng/g tissueであつた. 本例の摘出副腎のaldosterone 含量は腺腫と同様に $4400 \mathrm{ng} / \mathrm{g}$ tissue と高値であつ た.このことより，対側副督に腺腫の存在するこ とは否定的である (小島元子未発表データ).

副腎steroid hormoneの分析（図 5)：血 中各種steroidのbasal levelはprogesterone, DOC, 18-OH-DOCおよびaldosteroneはすべて分泌增加
が認められた。 また，17- $\alpha$-hydroxy progesterone は増加していたが， cortisolは正常範囲で，17$\alpha$-hydroxylase deficiencyは否定された。 また， aldosteroneが高值であつたことより11- $\beta$-hydroxylase deficiency 否定された。これらの結果より 既知の酵素欠損症は否定された。

摘出副腎の組織学的検討（図 6)：右副腎は $5 \times 4 \mathrm{~cm}, 4.6 \mathrm{~g}$ とほぼ正常範囲の外観を呈し, 割 面では最大 $2.5 \times 3 \times 5 \mathrm{~mm}$ の結節を含くめ, 数コの 小さな黄色結節を認め, 又, 中心静脈の周囲が黄 色となつていた。肉眼的に黄色にみえた中心部分 では球状帯から束状帯外層にかけて，やや過形成

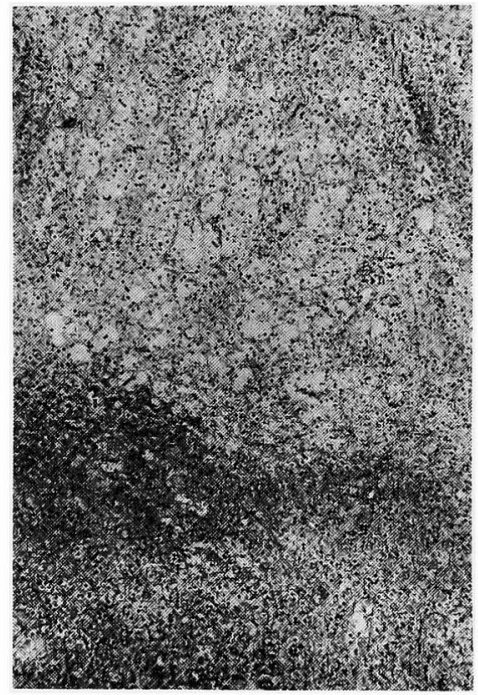

図 6.摘出副腎の組織像 (本例).結節状過形成を示 した。

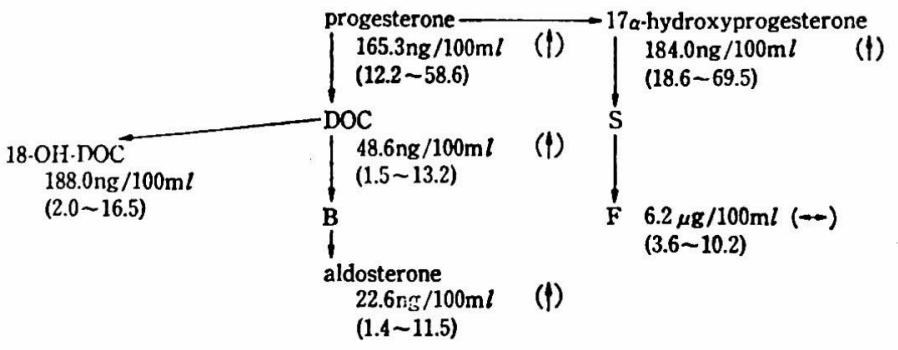

図 5. Steroid hormoneの分析.これらの結果より既知の酵素欠損は否定さ れた.（）内は正常値を示す. 


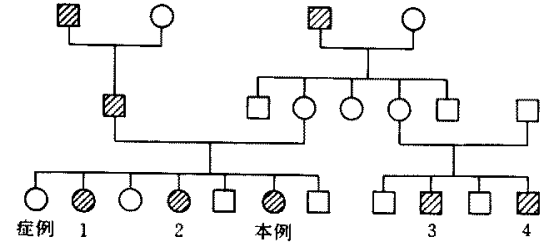

口等 ○女 㷌高血理

図7、家系図、母方を介したいとこ11人中特発性

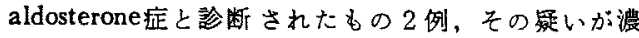
厚であるるの2例を認めた。

表 4 . 家族の検査成績

\begin{tabular}{|c|c|c|c|c|c|c|}
\hline 症例 & 年命 & 性 & 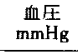 & $\begin{array}{l}\text { 血清K } \\
\mathrm{mEq} / l\end{array}$ & $\begin{array}{c}\mathrm{PRA} \\
\mathrm{ng} / \mathrm{ml}\end{array}$ & $\begin{array}{l}\mathrm{PAC} \\
\mathrm{ng} / \mathrm{dl}\end{array}$ \\
\hline 本例 & 17 & 女 & $190 / 120$ & 2.7 & 制制】 & 36.4 \\
\hline 1 & 27 & 女 & 高㿼厂 & & & \\
\hline 2 & 22 & 女 & $188 / 122$ & 2.9 & 抑制 ل & 35.7 \\
\hline 3 & 23 & 男 & $180 / 120$ & 2.8 & 㧕制 ل & 29.4 \\
\hline 4 & 19 & 男 & 高血压 & 低K & & \\
\hline
\end{tabular}

の傾向を示した，結節部分は皮質が深層よりに位 置し，明らかな結節状過形成で，被膜はなく，周 囲との境む明確でなく，lipoidに富む明細胞から なる束状帯細胞で，質的には外層の性格を示し た.

家族歴の検討： 図 7 と表 4 に家族歴とその検 査成績を示した。

同胞は 6 人で，女性 4 人中 3 人に高血圧を認 め, とくに症例 2 の22才の姉は血圧が188/122mm Hg と著明な高血圧を認め, 血清 $\mathrm{K} は 2.9 \mathrm{mEq} / l$ と低 $\mathrm{K}$ 血症で，血浆renin活性は抑制され，血将aldoster一 one濃度は $35.7 \mathrm{ng} / \mathrm{ml}$ と高値であつた。 また，母方 のいとこにあたる症例 3 は血圧が180/120 $\mathrm{mm} \mathrm{Hg}$ 高血圧があり，血清 $\mathrm{K} は 2.8 \mathrm{mEq} / l$ と低 $\mathrm{K}$ 血症を認 めた，又，renin分泌の抑制に関しては図 1 に示寸 如く, 無塩食, spironolactone $400 \mathrm{mg}$, hydrochlorothiazide $75 \mathrm{mg} 3$ 日間負荷する分泌刺激に対して も著明に抑制されていた，血捋aldosterone濃度は $29.4 \mathrm{ng} / \mathrm{ml}$ と高值であり, 又, 副腎scintigramより 右副腎腺腫が疑われた。しかし，腫痬は認められ ず，両側副腎の西全摘を施行し，組織学的にも， 両側副腎皮質の過形成を認め, 特発性aldosterone 症と診断された。 また，その弟も高血圧と低K血 症が方り，某病院にて原発性aldosterone症を疑わ れ検査中である。このよ5に母方を介した，いと こ11人中，特発性aldosterone症と診断が確定して いるむの 2 例, その疑が濃厚であるもの 2 例, 計 4 例に認められ，本症が家族的に発生していると 考えられた。

\section{考案}

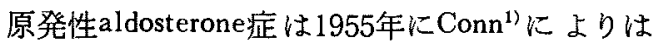
じめて報告された疾患で，副腎皮質に発生した腺 腫から過剩にaldosteroneが産生分泌され，その結 果，高血圧々電解質異常を来す。しかし，その 後, 臨床症状や検查成績が同様でありながら, 副 腎に孤立性腺腫を認めず，両側副質皮質に過形成 を認める症例が報告されて扣り，報告者により， その呼称はまちまちで, pseudo-primary aldosteronism ${ }^{5)}$, non-tumorous primary aldosteronism ${ }^{6)}$, idiopathic adrenal hyperplasia")等と称されている が， Liddleの命名にしたがつてidiopathic hyperaldosteronism $^{8)}$ (特発性aldosterone症) と称する場 合が多い.

副腎腺腫による原発性aldosterone症といわゆる idiopathic hyperaldosteronismとを鑑別することは 診断ならびに治療上重要なことである。

Conn" は， ${ }^{131}$ I-19-cholesterolによる副腎scintigramで，原発性aldosterone症では腺腫部に一致し て放射能の集中像がみられ，これに対して，特発 性aldosterone症では左右差のみられない場合が多 く, dexamethasone投与下でこれを行なうと両側 副腎とも集積像がみられなくなるので，両者の鑑 別が可能であるとした，本例はdexamethasone投 与下で， ${ }^{131}$ I-19-cholesterolを用いた副腎scintigraphyを行なつたところ，右側に ${ }^{131} \mathrm{I} の$ 取り込みを認 め, 腺腫の存在が強く疑われた。しかし, 手術に より腺腫は認められず, 組織学的にも過形成を認 め, 摘出側の副腎皮質 のaldosterone含量が高値 で，反対側の腺腫の存在が否定されたことより， 本例の場合はdexamethasone投与下に和いても腺 腫との鑑別が困難であつた。 又，原発性aldosterone症中特発性aldosterone症は共にrenin分泌の抑 
制があるが，その抑制の程度に差があり，過形 成例は腺腫例に比乙抑制の程度は軽く，明らか な差を認めたとの報告がある゙年，しかし，著者ら の経験した症例はいずれも著明なrenin分泌の抑 制を認め, 又, 無塩食, hydrochlorothiazide 75 $\mathrm{mg}$, spironolactone $400 \mathrm{mg}$ を 3 日間投与する強力な renin分泌刺激に対しても著明な抑制を示し，腺腫 例と過形成例とを鑑別することは出来なかつた。

又, aldosterone濃度は腺腫例に比し過形成例で有 意に低いとの報告 ${ }^{11)}$ もるが，本症例はいずれ も血将aldosterone濃度が著明に高值で腺腫例之 差を認めなかつた，又，左右の副腎静脈血中の aldosterone濃度を测定することは有用な鑑別法 で，著しい左右差を認めれば，高值を示す側に腺 腫があると診断出来る.しかし，本検查法は採血 に技術的煩雑さ上難しさがあり，本例も左右別に 副腎静脈から採血することが出来なかつた，又， 腺腫例であつても，後腹膜曌気体注入法による副 腎のX線断層写真で腫瘍陰影を示すことは希であ り，副腎静脈造影，副腎動脈造影によつても稙瘍 陰影が常に明確に出るとは限らない。このよう に, 形態学的ならびに内分泌学的にも両者を鑑別 することは困難であつた。しかし，副腎を摘出す るか, しないかは術後の管理を含めて重要な問題 であり，有効でから，簡便な鑑別法の開発が必要 であろら。

最近, 原発性aldosterone症と特発性aldosterone 症に打ける血浆aldosterone濃度の日内变動や，起 立等の刺激に対する反応の違いが検討され, 報告 されている。とれによると腺腫例には日内変動を 認めるか，過形成例には日内変動を認めないとい ら報告 ${ }^{11)}$ あるが，両者共にcortisolと同様の日

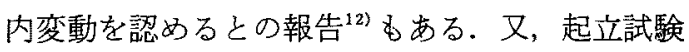
を加竞たとき，腺腫例はこれに反応しないのに対 して過形成例は反応し, aldosterone濃度は上昇す るといら ${ }^{11)-13)}$. 本例にかんしては日内変動, 起 立による変動は検討していないが，病態解明に 屯鑑別診断汇も，今後検討されてよい課題である 5 .
治㞠法に括いては内科的に行なら方法，外科的 に副腎摘出を行なら方法がある．副腎摘出が血圧 降下に対して有効であつたとするもの，無効であ つたとするものがあり，一定でない，副腎を摘出 することは術後の管理に問題がないわけではな い. Liddle $\mathrm{e}^{14)}$ は摘出副腎に腺腫を認めなかつたと き，他側の全摘出は生涯補充療法を必要とするた め避けるべきで, 2 分の 1 摘出にとどめ, 治療効 果が認められないときは内科的療法を行ならべき であると述べている。本例は 1 側副蜸摘出を行な つたが，明らかな血圧の降下は得られなかつた。

しかし，他側の摘出に関しては前述の術後の補充 療法の問題や，血圧が降下するという確証がな く，内科的に経過観察を行なつている.

本例は前述したように，里方を介したいとこ11 人中, 特発性aldosterone症と診断が確定している もの 2 例，その寲いが濃厚であるもの 2 例，計 4 例に認められ，本症が家族的に発生していると考 えられる.Connは23才以下に発生した過形成によ るaldosterone症 9 例を報告し，これをcongenital aldosteronism と仮称し，成人に発生する過形成以 よるaldosterone症をacquired aldosteronismとして 対比させ報告している nital aldosteronismでは既往歴を幼児期までにさ かのばることが出来, 副腎の全摘あるいは亜全摘 により血圧の改善を認め, acquired aldosteronism と明らかに相違しているとしている。これらの症 例は䣼欠損あるいはglucocorticoid responsive aldosteronismを否定されていないが興味深い報告 である.本邦に扣いても，熊谷らはアンヶートで 集積された原発性aldosterone症307例中に25才以 下の過形成によるaldosterone症が 10例含まれて おり，これらの症例に検討を加えて報告してい $る^{16)}$ ．うち 1 例は酵素欠損あるいはglucocorticoid responsive aldosteronismが考えられるが，他の症 例は酵素欠損やglucocorticoid responsive aldosteronismは否定してょいと考元られる.これらの症 例のなかに3才，13才，15才と若年であり，副腎 摘出あるいはspironolactoneの投与にも降王を認 
めない症例が含まれており，本例と同様になんら かの先天的素因が関与しているのではないかと考 えられる。

家族的に 発生する高血圧のなかにLiddle症候 群 ${ }^{17}$ があるが，本症候群では血将aldosterone濃度 が低值を示すので，本症候群は否定される.1966 年, Sutherland $5^{4)}$ は高血圧, 低 $\mathrm{K}$ 血症, aldosterone高值およびrenin活性の抑制を認め，酵素欠損 を認めない父子例を報告しておりこれらの症例 にdexamethasoneを投与したところ，血圧の降下

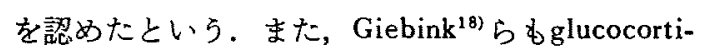
coid responsive aldosteronismの兄弟例を報告して いる. 本例はglucocorticoidに降圧を認めずこれ らの症例とは異なる。

著者らの調べた範囲では腺腫を伴つた原発性 aldosterone症や，いわゆる特発性aldosterone症が 家族的に発生しているという報告はない，本例は 酵素欠損やglucocorticoid responsive aldosteronism は否定され，いわゆる特発性aldosterone症と猃断 され，本症が家族的に発生していることより，若 年者の特発性aldosterone症の解明になんらかの示 㖫を与えるものと考えている.

謝辟稿を終るにあたり内分泌学的および組機学的 梌索御協力いただいた東北大学第二病理学教室小 島元子先生, 国立仙台病院研究検查科增田高行先生に 謝意を表します。

\section{文献}

1) Conn JW: Primary aldosteronism, a new clinical syndrome. J Lab clin Med 45: 6, 1955.

2) Sokolow $M$ and Perloff $D$ : The prognosis of essential hypertension treated conservatively. Circulation 23: 697, 1961.

3) 色川伸夫, 他 : 原発性 aldosterone 症における Renin 分泌刺激試験。日堅誌: $341,1976$.

4) Sutherland JA, et al: Hypertension, increased aldosterone secretion and low plasma renin activity relieved by dexamethasone. Canad Med Ass J 95: 1109, 1966.

5) Barer L, et al: Pseudo-primary aldosteronism. An entity distinct from trne primary aldosteronism. Circ Res $26 \& 27$ (Suppl I): 203, 1970.
6) Salti S, et al: Non-tumorous "primary" Aldosteronism: II Type not relieved by glucocorticoid. Canad Med Ass J 101: 11, 1969.

7) Luetscher JA, et al: Preoperative differentiation of adrenal adenoma from idiopathic adrenal hyperplasia in primary aldosteronism. Circ Res 34 \& 35 (Suppl I) : 175, 1974.

8) Laragh $\mathrm{JH}$, et al: Secondary aldosteronism and reduced plasma renin in hypertensive disease. Trans Ass Amer Phys 80: 168, 1967.

9) Conn JE, et al: The dexamethasone-modified adrenal scintiscan in hyporeninemic aldosteronism (tumor versus hyperplasia). A comparison with adrenal venography and adrenal venous aldosterone. J Lab clin Med 88: 841, 1976.

10) Stockigt JR, et al: Determination of plasma renin concentration by angiotensin $I$ immunoassay, diagnostic import of precise measurement of subnormal renin in hyperaldosteronism. Circ Res 28 (Suppl II): 175, 1971.

11) Mantero $F$, et al: Aldosterone regulation in primary aldosteronism: Differences between adenoma and bilateral hyperplasia. Clin Sci Mol Med 51: 329, 1976.

12) Schambelan $M$, et al: Circadian rhythm and effect of posture on plasma aldosterone concentration if primary aldosteronism. JCE \& $M$ 43: 115, 1976.

13) Ganguly A, et al: Control of plasma aldosterone in primary aldosteronism: Distinctionbetween adenoma and hyperplasia. JCE \& $\mathbf{M}$ 37:765, 1976.

14) Liddle GW: Management of aldosteronism. AJGP 54: 331, 1970.

15) Conn JW and Conn ES: Primary aldosteronism versus hypertensive disease with secondary aldosteronism. Recent Progr Hormone Res 17: 389, 1976.

16）能谷 朗,他：本邦における過去10年間の原発 性了ルドステロン症 307例の実熊. 日内分泌誌 $49: 1362,1974$.

17) Liddle GW, et al: A familial renal disorder simulating primary aldosteronism but with negligible aldosterone secretion. Trans Ass Amer Phys 76: 199, 1963.

18) Giebin KGS, et al: A kindred with familial glucocorticoid suppressible aldosteronism. JCE \& M 36: 715, 1973. 